\title{
Uraemic Pericarditis With Cardiac Tamponade : A Report of Four Cases
}

\author{
H. S. SYMONS,* M.B., M.R.C.P. ; O. M. WRONG,* B.M., M.R.C.P.
}

Pericarditis is a common complication of renal failure. It is usually an aseptic inflammatory process with fibrin formation but little fluid. Many authorities-for instance, de Wardener (1961) and Wood (1961)-make no mention of pericardial effusion resulting from uraemic pericarditis. However, Fishberg (1954) remarked that " exceptionally there is a considerable serous or haemorrhagic effusion," and Lowry and Boyd (1960), out of a total of 227 cases of uraemic pericarditis, recorded 58 with hydropericardium and 3 with massive haemopericardium.

Cardiac tamponade in uraemic pericarditis was first reported in the literature in 1956, when Goodner and Brown recorded the deaths of two young males with chronic renal disease. Acute right heart failure with pulsus paradoxus preceded death in both cases, and at necropsy 800 and $850 \mathrm{ml}$. of blood-stained fluid were found in the pericardial cavities. Since then six further cases have been reported (Guild, Bray, and Merrill, 1957 ; Hutt and Holmes, 1961 ; Merikas, Samartzis, and Marketos, 1962 ; Rappaport, 1962). In four of these cases some prolongation of life was obtained by pericardial tap ; one case improved spontaneously.

The following four cases of cardiac tamponade from uraemic pericarditis were seen in the renal unit at Hammersmith Hospital during 1961-2.

\section{Case 1. Chronic Glomerulonephritis}

A youth aged 18 had acute nephritis at the age of 7 . This insidiously entered a chronic phase with slightly elevated bloodpressure, persistent proteinuria, anaemia, osteodystrophy, and a gradually rising blood urea. On admission to hospital on 26 June 1962 he was moderately hypertensive (blood-pressure $180 / 100 \mathrm{~mm}$. $\mathrm{Hg}$ ) with clinical and electrocardiographic evidence of left ventricular hypertrophy, but there was no evidence of pericarditis. Blood urea was $505 \mathrm{mg} . / 100 \mathrm{ml}$., and serum sodium 134, serum potassium 4.8, serum chloride 88 , serum bicarbonate 10 , serum calcium 3.7 , and serum phosphate $7.2 \mathrm{mEq} /$ litre.

Haemodialysis was first performed on 4 July 1962 (blood urea $620 \mathrm{mg} . / 100 \mathrm{ml}$.) ; an arteriovenous teflon fistula was inserted in the left wrist as subsequent intermittent haemodialyses were planned. He was readmitted on 26 July with pericarditis and quickly developed a large pericardial effusion with signs of cardiac tamponadeparadoxical pulse $(10 \mathrm{~mm}$. $\mathrm{Hg}$ paradoxus), small pulse pressure (blood-pressure 150-160/120), jugular venous pressure elevated 8 $\mathrm{cm}$., increased cardiac dullness to percussion, a pericardial friction rub, and an enlarged tender liver. Chest $x$-ray examination and electrocardiogram confirmed the clinical diagnosis. Pericardial tap was performed on two occasions ( 3 and 7 August): 420 and $300 \mathrm{ml}$. of heavily blood-stained fluid were obtained. Haemodialysis was performed again on 8 August with satisfactory lowering of the blood urea to $88 \mathrm{mg} . / 100 \mathrm{ml}$. His convalescence was disturbed only by a large blood-stained left pleural effusion; pericardial friction disappeared and further pericardial aspiration was not required.

Repeated attacks of left ventricular failure preceded his final admission on 16 September. Pericardial friction was absent. Haemodialysis on two occasions was only of transient benefit, and he was discharged home, at his father's request, on 23 October. Death occurred on 6 November. Necropsy was not performed. * From the Postgraduate Medical School and the Hammersmith Hospital,

\section{Case 2. Renal Amyloidosis}

A man aged 40 was first seen in January 1960 because of chronic osteomyelitis of the sacrum and renal amyloidosis. He was moderately uraemic (blood urea $120 \mathrm{mg} . / 100 \mathrm{ml}$. By March 1961 he had developed malignant hypertension (blood-pressure 200/ $120 \mathrm{~mm} . \mathrm{Hg}$ ). This responded fairly well to guanethidine and hydrallazine. Two months later he was readmitted because of increasing uraemia (blood urea $330 \mathrm{mg} . / 100 \mathrm{ml}$.), severe anaemia (haemoglobin $37 \%$ ), and congestive cardiac failure. Transient pericardial friction was heard for the first time early in June. Haemodialysis was carried out in 7 June as the blood urea had risen to $430 \mathrm{mg} . / 100 \mathrm{ml}$.

His final admission was on 28 June because of increasing vomiting and fatigue. Examination showed a very dyspnoeic man with classical signs of cardiac tamponade-paradoxical pulse $(40 \mathrm{~mm}$. $\mathrm{Hg}$ paradoxus), jugular venous pressure elevated to the angle of the jaw, impalpable cardiac impulse, triple rhythm, pericardial rub no longer audible, and $4 \mathrm{~cm}$. of tender, enlarged liver. Chest $x$-ray examination revealed a large globular heart shadow and a left-sided pleural effusion, while an electrocardiogram was also suggestive of a pericardial effusion with decreased voltage of the QRS complexes and flattening and inversion of the $\mathrm{T}$ waves. His blood urea was 335 $\mathrm{mg} . / 100 \mathrm{ml}$.; serum sodium 130 , serum potassium 7.3 , serum chloride 90 , and serum bicarbonate $14 \mathrm{mEq} / 1$ : ; haemoglobin $39 \%$; with burr cells seen on film. Pericardial tap was not performed. Death occurred two days later on 30 June.

Necropsy showed chronic osteomyelitis of the sacrum, with amyloid deposits in the small contracted kidneys, thyroid, adrenals, spleen, oesophagus, and ileum. There was a haemorrhagic pericarditis with $300 \mathrm{ml}$. of blood in the pericardial sac. The haematocrit of this fluid was $24 \%$. The visceral and parietal layers of the pericardium were covered with shaggy fibrinous exudate.

\section{Case 3. Acute Tubular Necrosis}

A married woman age 51 had a radical mastectomy for scirrhous carcinoma of the left breast in June 1959. Bilateral oophorectomy was also performed, followed by a course of deep $x$-ray therapy. Metastatic spread to the mid-dorsal spine had occurred by December 1960. Bilateral adrenalectomy was performed in April 1961; unfortunately a right nephrectomy was also necessary because of trauma to the renal vein. Transient hypotension during the operation was followed by post-operative oliguria (urine volume 20-160 $\mathrm{ml}$. in the first six days) and a rising blood urea.

On admission to hospital on 20 April 1961, she had acidotic respirations and moderate oedema of the legs and sacrum. Her blood-pressure was $160 / 80 \mathrm{~mm}$. $\mathrm{Hg}$; the jugular venous pressure was not raised, and there was no pericardial friction rub. A chest $x$-ray examination showed nothing abnormal, and an electrocardiogram merely revealed T-wave inversion in leads $I$ and VI. Her blood urea was $375 \mathrm{mg} . / 100 \mathrm{ml}$. ; serum sodium 122 , serum potassium 5.8, serum chloride 79 , and serum bicarbonate $13 \mathrm{mEq} / \mathrm{l}$; haemoglobin $49 \%$; white-cell count $13,000 /$ c.mm. The blood film showed a keucoerythroblastic picture.

Haemodialysis was carried out on 22 April. Considerable oozing occurred from incisions in her groin and arm. Chloramphenicol $1 \mathrm{~g}$. daily was started for a coliform urinary infection. Pericardial friction was first heard on 25 April. By 29 April signs of early tamponade were noted-pulsus paradoxus, raised jugular venous pressure-while the electrocardiogram showed slight $S-T$ segment elevation over the chest leads and generally low voltage. Meanwhile her blood urea had risen to $440 \mathrm{mg} . / 100 \mathrm{ml}$. and further 
haemodialysis was performed on 30 April. Signs of cardiac tamponade became more pronounced during the three days following dialysis-pulsus paradoxus of $45 \mathrm{~mm}$. $\mathrm{Hg}$, blood-pressure $115 / 70$ $\mathrm{mm} . \mathrm{Hg}$, jugular venous pressure elevated to the angle of jaw, and heart sounds becoming fainter with disappearance of the pericardial friction rub. The clotting-time was $4 \frac{1}{2}$ minutes. On 3 May she complained of a sudden episode of shortness of breath and soon became unconscious and pulseless. On aspiration of $650 \mathrm{ml}$. of heavily blood-stained fluid from the pericardial sac there was an immediate return of pulse and consciousness. However, she relapsed and died shortly afterwards. Previous to this her oliguric renal failure had been improving and just before death her daily urine volume had risen to $350 \mathrm{ml}$.

Necropsy revealed a uraemic pericarditis with $500 \mathrm{ml}$. of what appeared to be pure blood in the pericardial cavity. Histological examination failed to show tumour deposits in the pericardium. The changes of acute tubular necrosis were present in the solitary left kidney.

\section{Case 4. Prostatic Hypertrophy-Chronic Pyelonephritis}

A 59-year-old man was admitted to the surgical department on 14 October 1961. He had a 12-months history of frequency of micturition (nocturia X 4), and for six months had experienced anorexia, vomiting, headache, and occasional hiccups. A few days before admission he developed a severe choking retrosternal pain. Examination revealed an ill-looking, dehydrated man. His bloodpressure was $160 / 70 \mathrm{~mm}$. Hg. A pericardial friction rub was present. There were crepitations at the left lung base. Rectal examination revealed an enlarged prostate. A chest $x$-ray film showed atrial fibrillation only. Blood urea was $355 \mathrm{mg} . / 100 \mathrm{ml}$. ; serum sodium 130, serum potassium 8.2 , serum bicarbonate 7 , serum calcium 3.6, and serum phosphate $7.8 \mathrm{mEq} / 1$; haemoglobin $44 \%$; and white-cell count $8,000 /$ c.mm.

"Resonium-A" was given by mouth because of hyperkalaemia. On 16 October peritoneal dialysis was begun because of continuing oliguria and rising blood urea $(465 \mathrm{mg} . / 100 \mathrm{ml}$.). By 18 October there were signs of cardiac tamponade (15 mm. of pulsus paradoxus) and a pericardial tap was performed; only $30 \mathrm{ml}$. of blood-stained fluid was obtained, however. Later the same day the patient became dyspnoeic and his blood-pressure fell to $120 / 60 \mathrm{~mm}$. Hg. Coarse crepitations were audible all over both lungs. Despite venesection and tourniquets applied to his limbs death occurred soon after.

Necropsy confirmed the clinical diagnosis of pericardial effusion and pulmonary oedema. The pericardial sac contained $800 \mathrm{ml}$. of heavily blood-stained fluid. The prostate was hypertrophied, with a trabeculated bladder and active cystitis. There was also bilateral hydronephrosis, hydroureter, and pyelonephritis.

\section{Discussion}

Cardiac tamponade is not a common complication of uraemic pericarditis. However, it is important to recognize the development of this complication as it is readily amenable to treatment. Its appearance is not necessarily a prelude to death, for one patient (Case 1) lived for three months after pericardial aspiration. Guild et al. (1957) have emphasized the reversibility of uraemic cardiac tamponade in their report of two patients who survived this complication after successful aspiration.

The development of tamponade in cases of pericardial effusion depends not only on the amount of fluid within the sac but also on the rapidity of collection of this fluid ( $\mathrm{Yu}$, Lovejoy, Joos, Nye, and Simpson, 1953). In each of the above four cases the symptoms and signs arose acutely over a period of a few hours or days, and the speed of clinical deterioration was more rapid than is usual in cardiac tamponade from other causes. This may have been related to the fact that the pericardial fluid was pure blood in two cases, and heavily blood-stained in the other two, suggesting bleeding into the pericardial cavity. Uraemic subjects of ten have a bleeding tendency, and in Case 3 this was apparent from persistent oozing from the groin and arm incisions performed for haemodialysis. Indeed, in this patient cardiac tamponade appears to have been aggravated by the second haemodialysis; the critical factor might have been heparinization. Anticoagulants cannot be held responsible for the development of haemopericardium in the other three cases (see accompanying Table). Indeed, in Case 1, resolution of the pericardial effusion was hastened after his final dialysis and pericardial friction was not heard again.

\begin{tabular}{|c|c|c|c|c|c|c|}
\hline $\begin{array}{l}\text { Case } \\
\text { No. }\end{array}$ & $\begin{array}{l}\text { Sex } \\
\text { and } \\
\text { Age }\end{array}$ & Renal Disease & $\begin{array}{c}\text { Blood } \\
\text { Urea at } \\
\text { Time of } \\
\text { Death } \\
(\mathrm{mg} / \\
100 \mathrm{ml} .)\end{array}$ & $\begin{array}{c}\text { Duration } \\
\text { of } \\
\text { Observed } \\
\text { Peri- } \\
\text { carditis }\end{array}$ & $\begin{array}{l}\text { Interval } \\
\text { Between } \\
\text { Haemo- } \\
\text { dialysis } \\
\text { and } \\
\text { Cardiac } \\
\text { Tam- } \\
\text { ponade }\end{array}$ & $\begin{array}{c}\text { Peri- } \\
\text { cardial } \\
\text { Contents } \\
\text { at } \\
\text { Necropsy }\end{array}$ \\
\hline 1 & M 18 & $\begin{array}{l}\text { Chronic } \\
\text { glomerulo- } \\
\text { nephritis }\end{array}$ & $>600$ & 2 weeks & 3 weeks & $\begin{array}{c}\text { No } \\
\text { necropsy }\end{array}$ \\
\hline 2 & M 40 & $\begin{array}{l}\text { Renal amyloidosis. } \\
\text { Chronic osteo- } \\
\text { myelitis of } \\
\text { sacrum. Malig- } \\
\text { nant hyper- } \\
\text { tension }\end{array}$ & 335 & 9 weeks & 3 weeks & $\begin{array}{l}300 \mathrm{ml} . \\
\text { blood }\end{array}$ \\
\hline 3 & F 51 & $\begin{array}{l}\text { Post-operative } \\
\text { acute tubular } \\
\text { necrosis in } \\
\text { solitary kidney } \\
\text { (Metastatic } \\
\text { breast carcinoma) }\end{array}$ & 119 & 8 days & 3 days & $\begin{array}{l}500 \mathrm{ml} . \\
\text { blood }\end{array}$ \\
\hline 4 & M 59 & $\begin{array}{l}\text { Benign prostatic } \\
\text { hypertrophy } \\
\text { with bilateral } \\
\text { hydronephrosis } \\
\text { and chronic } \\
\text { pyelonephritis }\end{array}$ & 520 & 4 days & $\begin{array}{c}\text { No } \\
\text { haemo- } \\
\text { dialysis }\end{array}$ & $\begin{array}{l}800 \mathrm{ml} \text {. } \\
\text { blood- } \\
\text { stained } \\
\text { fluid }\end{array}$ \\
\hline
\end{tabular}

The exact cause of uraemic pericarditis is still unknown, but in clinical practice the incidence and severity of pericarditis seem to be directly related to the severity of renal failure. The Table shows no direct relationship between the measured level of blood urea and cardiac tamponade, but such a relationship might have been obscured in Cases 2 and 3 by treatment with haemodialysis during the last few weeks of life.

\section{Summary}

Cardiac tamponade is a rare complication of uraemic pericarditis. Four new cases are described. The condition may be successfully treated by pericardial aspiration, and uraemic patients should therefore not be allowed to die of tamponade if their renal failure is potentially reversible.

We would like to thank Professor R. Shackman for his supervision of the haemodialyses and for permission to publish details of Case 4 .

\section{REFERENCES}

Fishberg, A. M. (1954). Hypertension and Nephritis, 5th ed. Bailliere, Tyndall and Cox, London. Goodner, C. J., and Brown, H. (1956). F. Amer. med. Ass., 162, 1459. .
Guild, W. R., Bray, G., and Merrill, J. P. (1957). New Engl. F. Med., 257, 230 .

Hutt, M. P., and Holmes, J. H. (1961). Arch. intern. Med., 108, 226. Lowy, A. C., and Boyd, L. J. (1960). Exp. Med. Surg., 18, 90. Merikas, G., Samartzis, M., and Marketos, S. (1962). New Engl. 7. Med., 266, 1089 .

Rapnaport, H. R. (1962). 7. Mt Sinai Hosp., 29, 334.

de Wardener, H. E. (1961). The Kidney, 2nd ed. Churchill, London.

de Wardener, H. E. (1961). The Kiseases of the Heart and Circulation, 2nd ed. Eyre and Spottiswoode, London.

Yu, P. N. G., Lovejoy, F. W., Joos, H. A., Nye, R. E., and Simpson, J. H. (1953). Ann. intern. Med., 39, 928. 